\title{
A reliable and effective method of DNA isolation from old human blood paper cards
}

Yang Song ${ }^{1+}$, Abrahim Fahs ${ }^{2+}$, Charles Feldman ${ }^{3}$, Suraj Shah ${ }^{2}$, Yali Gu ${ }^{2}$, Yifan Wang ${ }^{2}$, Roberto F Machado ${ }^{2}$, Richard G Wunderink ${ }^{4}$ and Jiwang Chen ${ }^{2 *}$

\begin{abstract}
Blood paper cards provide an effective DNA storage method. In this study, we used three DNA dissolving reagents (Tris-EDTA [TE] buffer, Tris-HCl buffer, and water) and one common commercially available kit (DN131 from MRC Inc) to elute DNA from 105 human blood paper cards collected up to 10 years ago. These DNA samples were used as templates for amplification of a single nucleotide polymorphism (SNP, C125T) region of human caspase-12 by PCR and a specific Taqman genotyping assay using the same amount of DNA. We show that DNA isolated by Tris-HCl buffer has higher yield and quality in comparison to DN131 solution. PCR success rate to amplify caspase-12 C125T SNP using Tris-HCl is comparable to the method using DN131 (89.5\% vs 87.6\%). The Taqman genotyping success rate using Tris- $\mathrm{HCl}$ is higher than using DN131 (81.9\% vs 70.5\%). Using TE or water, PCR success rates are lower than using DN131 (73.3\% [TE]; 72.4\% $\left.\left[\mathrm{H}_{2} \mathrm{O}\right]\right)$, but Taqman genotyping success rates are comparable to the method using DN131 (70.5\% [TE]; 79.1\% [ $\left.\mathrm{H}_{2} \mathrm{O}\right]$ ). We concluded that using Tris- $\mathrm{HCl}$ is a reliable and effective method to elute DNA from old human blood paper cards. The crude DNA isolated by Tris- $\mathrm{HCl}$ can be used to study genetic polymorphisms in human populations.
\end{abstract}

Keywords: Blood paper card; DNA isolation; DN131; PCR; Caspase-12

\section{Introduction}

Blood paper cards are widely used in biomedical research to maintain human genomic DNA and blood pathogen DNA for genetic, pharmacogenetic and clinical testing. They provide an easier collection, transportation, and storage methods than other protocols (Dobbs et al. 2002; Mas et al. 2007; Soetens et al. 2008; Hardin et al. 2009; Ataei et al. 2011; Klassen et al. 2012; Klassen et al. 2013). Blood paper cards can be stored at room temperature under dry conditions with a desiccant, and do not need other special storage requirements. On average, blood paper cards can be stored ten years post-collection, ensuring that DNA can be accessed for future experimentation.

Currently, several kits are commercially available for DNA isolation from blood paper cards. These kits include GenSolve (Cat.\# WB100050, BTC Private Limited)

\footnotetext{
* Correspondence: chenjw@uic.edu

${ }^{\dagger}$ Equal contributors

${ }^{2}$ Section of Pulmonary, Critical Care, Sleep and Allergy, Department of Medicine, University of Illinois at Chicago, Chicago, IL 60612, USA Full list of author information is available at the end of the article
}

(Richard et al. 2011; Phyo et al. 2012), forensicGEM (Cat.\# 95044-090, Zygem Corporation) (Moss et al. 2003), DNA IQ (Cat.\# DC6700, Promega) (Barbaro et al. 2004; Rohland and Hofreiter 2007), and DNAzol (DN131, MRC Inc) (Chomczynski et al. 1997; Mackey et al. 1998; Chomczynski et al. 1998; Haak et al. 2009; Turner et al. 2011; Knowles et al. 2012). DN131 is a commonly used reagent for blood paper card DNA isolation because its protocol is straightforward, and the supernatant with blood paper card post centrifugation can be directly used for amplification of targeted genes by polymerase chain reaction (PCR). However, the volume of the supernatant cannot exceed $10 \%$ of the total PCR volume when DN131 kit is utilized. In addition, DNA isolated by DN131 includes excess proteins, which will further dampen efficiency of PCR amplification. Previously our team had used Tris- $\mathrm{HCl}$ (10 mM, pH7.4) and achieved a high success rate for mouse genotyping (Sysol et al. 2013). We therefore hypothesized that DNA dissolving solutions including Tris- $\mathrm{HCl}$, TE or water may be feasible for blood paper card DNA isolation. 
The aim of this study was to investigate the feasibility and effectiveness using Tris- $\mathrm{HCl}(10 \mathrm{mM}, \mathrm{pH} 7.4)$, TrisEDTA buffer (TE, $10 \mathrm{mM}, \mathrm{pH} 7.6$ ), water and DN131 to isolate DNA from 105 human blood paper cards. In addition, we examined whether the crude DNA isolated by these solutions was sufficient to amplify caspase-12 C125T SNP (rs\#497116). To our knowledge, this is the first comprehensive study to compare the effectiveness and efficiency using these easily obtained laboratory solutions for blood paper card DNA isolation.

\section{Materials and methods Reagents}

Reagents were from Sigma (St Louis, MO, USA), unless otherwise stated. The four liquid solutions used for DNA isolation from blood paper cards were: Tris- $\mathrm{HCl}(10 \mathrm{mM}$, pH7.4), Tris-EDTA (TE) buffer (10 mM, pH7.6), sterilized water, DN131 (Molecular Research Center, InC).

\section{Human blood paper cards}

105 human blood paper cards were collected in South Africa up to 10 years ago using Schleicher \& Schuell (S \& S) 903 paper cards (Whatman Ltd). S \& S 903 is a FDA approved medical device recommended by the International Screening Community for Neonatal Screening worldwide. This blood paper card is also widely used for the studies of personalized medicine, with its paper manipulated for strictly quality-controlled for serum uptake, absorption characteristics and lot-to-lot consistency, ensuring reproducibility of results. Each blood paper card has been well separated by a sterilized plastic bag. Five circular blood samples were located in each blood paper card, and each blood circle contained a blood volume of approximately $75 \mu$ l. Endorsement to use these human blood paper cards has been permitted by the Northwestern University Institutional Review Board.

\section{DNA isolation}

Outlined in Table 1 is the DNA isolation procedure utilized for this study. Four blood circles from each sample were used and cut into small pieces using a sterilized

Table 1 Procedure for DNA isolation from blood paper card

\begin{tabular}{cl}
\hline Step & Procedure \\
\hline 1 & Cut a blood paper card spot to 4 small pieces of equal size \\
\hline 2 & $\begin{array}{l}\text { Transfer paper card pieces to an eppendorf tube with an } \\
\text { isolation solution }\end{array}$ \\
\hline 3 & Rotate the tubes overnight at $4^{\circ} \mathrm{C}$ \\
\hline 4 & Heat the tubes at $95^{\circ} \mathrm{C}$ for 10 min \\
\hline 5 & Centrifuge at $10,000 \mathrm{~g}$ at the room temperature for 10 min \\
\hline
\end{tabular}

scissor and forceps. The small pieces from each blood circle were distributed into a $1.5 \mathrm{ml}$ sterilized Eppendorf tube. As a result, four blood circles from one human sample were placed into four Eppendorf tubes, each containing one of the four different DNA dissolving solutions mentioned as above. The volume of each reagent used was $500 \mu \mathrm{l}$, ensuring that the entire blood paper card pieces were immersed within the reagent. Tubes were then placed in a rotator overnight at $4^{\circ} \mathrm{C}$. After an overnight rotation, samples were heated at $95^{\circ} \mathrm{C}$ for $10 \mathrm{~min}$, and then centrifuged at room temperature for 1 minute at $10,000 \mathrm{~g}$. The supernatant (approximately $480 \mu \mathrm{l}$ ) was transferred into a new $1.5-\mathrm{ml}$ Eppendorf tube. DNA quantity and quality measured using ND-1000 Spectrophotometer (Nano-Drop technologies, Inc). DNA quality was evaluated by the ratios of A260/A280 and A260/A230 (absorption values at the different wavelengths).

\section{PCR analysis}

The supernatant obtained as above was directly used for amplification of a SNP (rs\#497116) in human caspase-12 by PCR. The sequences of the two primers we used are: forward primer, 5' GTCATTCTGTGTGTATTAATTG C3'; reverse primer, 5' CCTATAATATCATACATCTT GCTC3'. Two different PCR amplification systems were used. System 1: $25 \mu$ l of Platinum PCR SuperMix (Cat.\# 11306-016, Life Technologies Inc), $0.5 \mu \mathrm{l}$ of mixed forward and reverse primers $(10 \mu \mathrm{M})$ with a certain amount of crude DNA solution in a final reaction volume of $28 \mu$ l. System 2: using GoTaq DNA polymerase (Cat.\# M3005, Promega Corporation). We added $5 \mu \mathrm{l}$ of $5 \times$ PCR buffer, $0.5 \mu \mathrm{l}$ of mixed forward and reverse primers $(10 \mu \mathrm{M}), 0.3 \mu \mathrm{l}$ Taq enzyme (5 units/ $\mu \mathrm{l}), 1 \mu \mathrm{l} \mathrm{dNTP}$ (10 mM), $0.6 \mu \mathrm{l} 25 \mathrm{mM} \mathrm{MgCl}$ with a certain amount of crude DNA solution in a final reaction volume of $25 \mu \mathrm{l}$. In system 1, the same amount of DNA was used for each sample according to $2 \mu \mathrm{l}$ DNA amount isolated by DN131; in system 2, we used $2 \mu \mathrm{l}$ DNA isolated by DN131, but with $16 \mu$ DNA from the other three DNA isolation solutions. In both systems, the DNA volume from DN131 group we used $(2 \mu \mathrm{l})$ was approximately $10 \%$ of the total PCR volume according to the manufacturer's instruction. Cycling conditions were $94^{\circ} \mathrm{C} 2 \mathrm{~min}$, $55^{\circ} \mathrm{C} 40 \mathrm{~s}, 72^{\circ} \mathrm{C} 1.5 \mathrm{~min}$, two cycles $\rightarrow 94^{\circ} \mathrm{C} 20 \mathrm{~s}, 55^{\circ} \mathrm{C}$ $40 \mathrm{~s}, 72^{\circ} \mathrm{C} 1 \mathrm{~min}, 40$ cycles $\rightarrow 72^{\circ} \mathrm{C} 8 \mathrm{~min}$. Agarose-gel electrophoresis (2\%) and ethidum bromide staining were used to check the PCR product, whose size is approximately 314 bp.

\section{Taqman genotyping assay}

A Taqman genotyping assay [Applied Biosystems Inc $(\mathrm{ABI})$, Foster City, $\mathrm{CA}$ ] was also used to genotype the caspase-12 C125T SNP using the same amount of DNA 
Table 2 Quantity and quality of DNA isolated from old human blood paper cards using different reagents

\begin{tabular}{|c|c|c|c|}
\hline \multirow{3}{*}{ Methods } & \multirow{3}{*}{$\begin{array}{c}\text { DNA quantity } \\
\text { (ng/ml) } \\
\text { (min, max) }\end{array}$} & \multicolumn{2}{|c|}{ DNA quality } \\
\hline & & A260/A280 & A260/A230 \\
\hline & & (min, max) & $(\min , \max )$ \\
\hline \multirow[t]{2}{*}{ DN 131} & $103.3 \pm 8.6$ & $2.07 \pm 0.6$ & $0.06 \pm 0.01$ \\
\hline & $(-64.9,566.9)$ & $(-6.64,52.18)$ & $(-0.03,0.37)$ \\
\hline \multirow[t]{2}{*}{ Tris- $\mathrm{HCl}$} & $190.0 \pm 6.1$ & $1.5 \pm 0.01$ & $0.5 \pm 0.01$ \\
\hline & $(62.7,397.7)$ & $(1.17,1.72)$ & $(0.35,0.75)$ \\
\hline \multirow[t]{2}{*}{$\overline{\mathrm{TE}}$} & $183.5 \pm 6.4$ & $2.08 \pm 0.1$ & $1.06 \pm 0.1$ \\
\hline & $(54.2,444.8)$ & $(1.30,8.90)$ & $(0.4,6.25)$ \\
\hline \multirow[t]{2}{*}{$\mathrm{H}_{2} \mathrm{O}$} & $203.5 \pm 9.0$ & $1.5 \pm 0.01$ & $0.4 \pm 0.01$ \\
\hline & $(38.8,489.2)$ & $(1.23,1.68)$ & $(0.22,0.82)$ \\
\hline
\end{tabular}

In each space, values are represented as mean \pm standard error. The minimum $(\min )$ and maximum $(\max )$ values are shown in parenthesis.

isolated from the four solutions mentioned as above. The specific genotyping assay ID number for caspase- 12 C125T is C_2411553_20. The genotyping was conducted in a 384-well plate with a total volume $10 \mu \mathrm{l}$ in a $\mathrm{C}^{1000^{\mathrm{mm}}}$ Thermal Cycler (Bio-Rad). The DNA amount we used is according to the DNA amount in $1 \mu \mathrm{l}$ from DN131 isolated DNA samples.

\section{Data analysis}

All the data were reported as mean and standard error (SEM). DNA concentration and DNA quality data analysis were performed on average of two repeated measurements. Statistical analysis was performed using GraphPad Prism 5.1 (GraphPad Software, La Jolla, CA). Normality of data distribution was assessed by using the Kolmogorov-Smirnov test. Because only DNA concentrations and A260/A230 ratios from the four groups were normally distributed, $T$-test was used to evaluate their differences between methods. Wilcoxon Rank-Sum test was used to examine the A260/A280 differences between methods including DN131. The agreement between DN131 and others (Tris- $\mathrm{HCl}, \mathrm{TE}, \mathrm{H}_{2} \mathrm{O}$ ) was assessed by Bland-Altman plots using BA.plot package in R (Myles and Cui 2007). The differences between
DN131 and our methods (Tris- $\mathrm{HCl}, \mathrm{TE}, \mathrm{H}_{2} \mathrm{O}$ ) were plotted against the average values $\left(\left[\mathrm{DN} 131+\mathrm{H}_{2} \mathrm{O}\right.\right.$ (TE or Tris- $\mathrm{HCl})] / 2$ ) respectively. $95 \%$ prediction intervals (limits of agreement) of differences and Pearson correlation for "line of agreement" are also reported. The mean difference (Tris- $\mathrm{HCl}$ [TE or $\mathrm{H}_{2} \mathrm{O}$ ] - DN131) was defined by a solid horizontal line. Two dashed lines represent the two standard deviations (SD) above and below the mean difference line, which correspond to the limits of agreement. Line of agreement was plotted by considering linear relation between the difference and mean. $p<0.05$ was considered statistically significantly different.

\section{Results}

\section{Quantity and quality of isolated DNA}

DNA from 105 human blood paper cards was successfully recovered. Quantity and quality of these isolated DNA samples are shown in Table 2 and Figures 1-2. Using the same size of blood paper cards, concentrations of DNA recovered by Tris- $\mathrm{HCl}, \mathrm{TE}$, water and DN131 buffer were $190.0 \pm 6.1,183.5 \pm 6.4,203.5 \pm 9.0$ and $103.3 \pm 8.6 \mathrm{ng} / \mathrm{ml}$, respectively. Significantly higher DNA yield was obtained using Tris- $\mathrm{HCl}, \mathrm{TE}$, and water than using DN131 $(p<0.05$, Figure 1A). Minimum and maximum values of DNA concentrations in four different groups were shown in Table 2, in which the variation between minimum and maximum values was greater in DN131 group than the other groups.

DNA quality was assessed by A260/A280 and A260/ A230. The mean \pm standard errors of these ratios with their minimum and maximum values were shown in Table 2 and Figure 1. According to Wilcoxon Rank-Sum test of the A260/A280 differences between methods, Tris- $\mathrm{HCl}, \mathrm{TE}$ and $\mathrm{H} 2 \mathrm{O}$ groups were significantly different from DN131 group $(p<0.05)$. In terms of A260/ A230 ratio, DNA isolated by DN131 had the lowest values $(0.06 \pm 0.01, p<0.05)$, compared to the ones by Tris- $\mathrm{HCl}(0.5 \pm 0.01)$, TE $(1.06 \pm 0.1)$ or water $(0.4 \pm 0.01)$. In terms of both A260/A280 and A260/A230 ratio differences between the minimum and maximum values, DN131 group was greater than the other three groups,
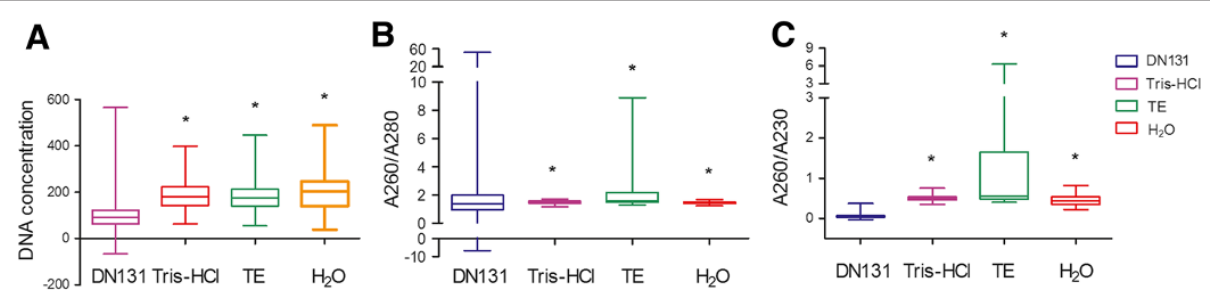

Figure 1 Concentrations, A260/A280 and A260/A230 ratios of DNA isolated from old human blood paper cards with the four different reagents (DN131, Tris-HCl, TE, $\mathbf{H}_{2}$ O). A. DNA concentrations (ng/ $\left.\mathrm{\mu l}\right)$; B. A260/A280 ratios; C. A260/A230 ratios. *, $p<0.05$, compared to DN131 group. T-test was performed for DNA concentrations and A260/A230 ratios because these data are normally distributed, while A260/A280 data are not normally distributed. Wilcoxon Rank-Sum test was used to examine the A260/A280 differences between methods including DN131. 

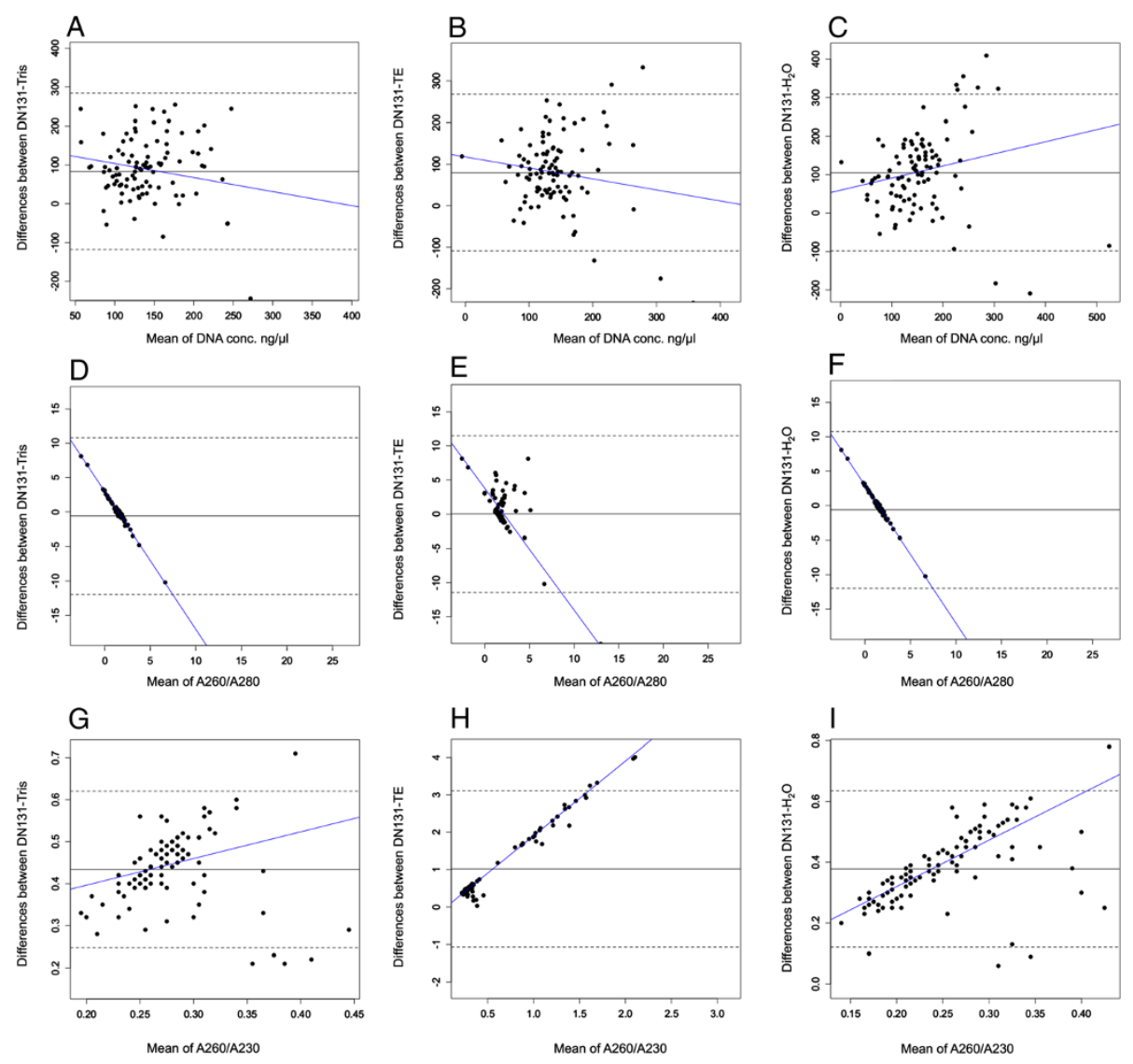

Figure 2 Bland-Altman Plots of DNA concentrations, A260/A280 and A260/A230 ratios between the two methods using DN131 and using our solutions (Tris-HCl, TE or water). A. Bland-Altman Plot of DNA concentrations between DN131 and Tris- $\mathrm{HCl}$. Correlation R=0.38 $(p<0.0001)$, slope $=-0.76(p<0.001)$, intercept $=193.27(p<0.0001)$; B. Bland-Altman Plot of DNA concentrations between DN131 and TE. Correlation $R=0.28(p<0.004)$, slope $=-0.46(p=0.004)$, intercept $=145.59(p<0.0001)$; C. Bland-Altman Plot of DNA concentrations between DN131 and $\mathrm{H}_{2} \mathrm{O}$. Correlation $\mathrm{R}=0.05(p=0.55)$, slope $=0.32(p=0.96)$, intercept $=59.65(p=0.99)$; $\mathbf{D}$. Bland-Altman Plot of A260/A280 ratios between DN131 and Tris-HCl. Correlation $\mathrm{R}=0.99(p<0.0001)$, slope $=-2.0(p<0.0001)$, intercept $=2.95(p<0.0001)$; E. Bland-Altman Plot of A260/ A280 ratios between DN131 and TE. Correlation $R=0.97(p<0.0001)$, slope $=-1.97(p<0.0001)$, intercept $=3.51(p<0.0001)$; F . Bland-Altman Plot of A260/A280 ratios between DN131 and $\mathrm{H}_{2} \mathrm{O}$. Correlation $\mathrm{R}=0.99(p<0.0001)$, slope $=-20(p<0.0001)$, intercept $=2.91(p<0.0001)$; $\mathbf{G}$. BlandAltman Plot of A260/A230 ratios between DN131 and Tris-HCl. Correlation $\mathrm{R}=0.06(p=0.57)$, slope $=0.64(p=0.99)$, intercept $=0.27(p=0.99)$; H. Bland-Altman Plot of A260/A230 ratios between DN131 and TE. Correlation $R=0.99(p<0.0001)$, slope $=1.99(p<0.0001)$, intercept $=-0.12$ $(p=0.007)$; I. Bland-Altman Plot of A260/A230 ratios between DN131 and $\mathrm{H}_{2} \mathrm{O}$. Correlation $\mathrm{R}=0.47(p<0.0001)$, slope $=0.97(p<0.0001)$, intercept $=0.13(p=0.007)$.

and TE group was higher than Tris- $\mathrm{HCl}$ or $\mathrm{H}_{2} \mathrm{O}$ group (Table 2).

According to the Bland-Altman plots (Figure 2), most of the points lie within the $95 \%$ limits of agreement. The mean DNA concentration difference between $\mathrm{H}_{2} \mathrm{O}$ and DN131 was $105.21 \mathrm{ng} / \mu \mathrm{l}$, while the limit of agreement was -98.32 to 308.74 . Most of the spots (96 out of 104) were within the limit of agreement. The slope of line of agreement almost parallel to the axis of average of $\mathrm{H}_{2} \mathrm{O}$ and DN131 ( $p=0.96, \mathrm{R}=0.05)$, which indicates the concordance between $\mathrm{H}_{2} \mathrm{O}$ and DN131 was independent of the two methods. The mean DNA concentration difference between the TE and DN131 was $79.72 \mathrm{ng} / \mu \mathrm{l}$, while the limit of agreement was -108.64 to 268.07 . Most of the spots (99 out of 104) were within the limit of agreement. The slope of line of agreement was not parallel to the axis of average of the TE and DN131 $(p=0.004, \mathrm{R}=0.28)$. The mean DNA concentration difference between the Tris- $\mathrm{HCl}$ and DN131 was $83 \mathrm{ng} / \mu \mathrm{l}$, while the limit of agreement was -118.11 to 284.13 . Most of the spots (99 out of 104) were within the limit of agreement. The slope of line of agreement was not parallel to the axis of average of the Tris- $\mathrm{HCl}$ and DN131 $(p<0.0001, \mathrm{R}=0.38)$. Agreements were consistently high at $\mathrm{TE}$ and $\mathrm{Tris}-\mathrm{HCl}$, which further supports the significantly higher DNA yield obtained using Tris- $\mathrm{HCl}$ or TE than using DN131 
based on T-test. In addition, the mean differences in the A260/280 ratios between DN131 and Tris- $\mathrm{HCl}$, TE or $\mathrm{H}_{2} \mathrm{O}$ were -0.58 (from -11.97 to 10.8 , limit of agreement), 0.035 (from -11.42 to 11.5 ) and -0.61 (from -11.98 to 10.76), respectively. These mean differences of the A260/ A280 ratios combined their slope p values (all $<0.0001$ ) indicates that there is significant difference in the DNA quality assessed by the A260/A280 ratios between methods including DN131, which is consistent with our Wilcoxon Rank-Sum test (Figure 1B). In addition, the mean differences in the A260/230 ratios between DN131 and Tris- $\mathrm{HCl}$, TE or $\mathrm{H}_{2} \mathrm{O}$ were 0.43 (from 0.25 to 0.62 , limit of agreement), 1.02 (from -1.07 to 3.11 ) and 0.37 (from 0.12 to 0.64 ), respectively. All the agreements were consistently high at Tris- $\mathrm{HCl}$, TE and $\mathrm{H}_{2} \mathrm{O}$, which further confirms the DNA quality evaluated by A260/A230 in Tris- $\mathrm{HCl}, \mathrm{TE}$ or $\mathrm{H}_{2} \mathrm{O}$ is better than DN131 group based on $T$-test (Figure $1 \mathrm{C}$ ).

\section{PCR amplification and Taqman genotyping assay of caspase-12 C125T SNP}

PCR results using DNAs isolated by the four different reagents with two different PCR systems were analyzed and compared using agarose gel electrophoresis. A representative image of PCR-amplified caspase-12 C125T SNP fragment was demonstrated for system 1
(Figure 3A) and system 2 (Figure 3C), respectively. The PCR-amplified band density was quantified and shown in Figure 3B for system 1 and in Figure 3D for system 2. As shown in Table 3, using the same amount of DNA template (system 1), PCR success rate is highest for Tris- $\mathrm{HCl}$ (89.5\%, 94/105), with 87.6\% (92/105) for DN131, 73.3\% $(77 / 105)$ for $\mathrm{TE}$ and $72.4 \%(76 / 105)$ for $\mathrm{H}_{2} \mathrm{O}$. However PCR band density in DN131 group is significantly higher than the other three groups (Figure $3 \mathrm{~B}, \mathrm{p}<0.05$ ). When volume of DNA samples isolated by Tris- $\mathrm{HCl}$, TE and water was increased to $16 \mu \mathrm{l}$ (system 2), PCR amplification success rates were increased to $96.1 \%(99 / 103)$, $88.5 \%(92 / 105)$ and $78.1 \%(82 / 105)$, respectively. Meantime, PCR band density values in Tris- $\mathrm{HCl}, \mathrm{TE}$ and water groups are all significantly higher than DN131 group (Figure 3D, $p<0.001$ ).

When the same amount of DNA was used, success rates for Taqman genotyping of caspase-12 C125T SNP were shown in Table 3. Genotyping success rate for Tris-HCl (86/103; 81.9\%) was the most successful, second was for water $(79 / 105 ; 79.1 \%)$. DN131 or TE (both 74/105-70.5\%) was the least successful.

\section{Discussion}

In this study, we investigated for the first time about the feasibility of using three common DNA dissolving
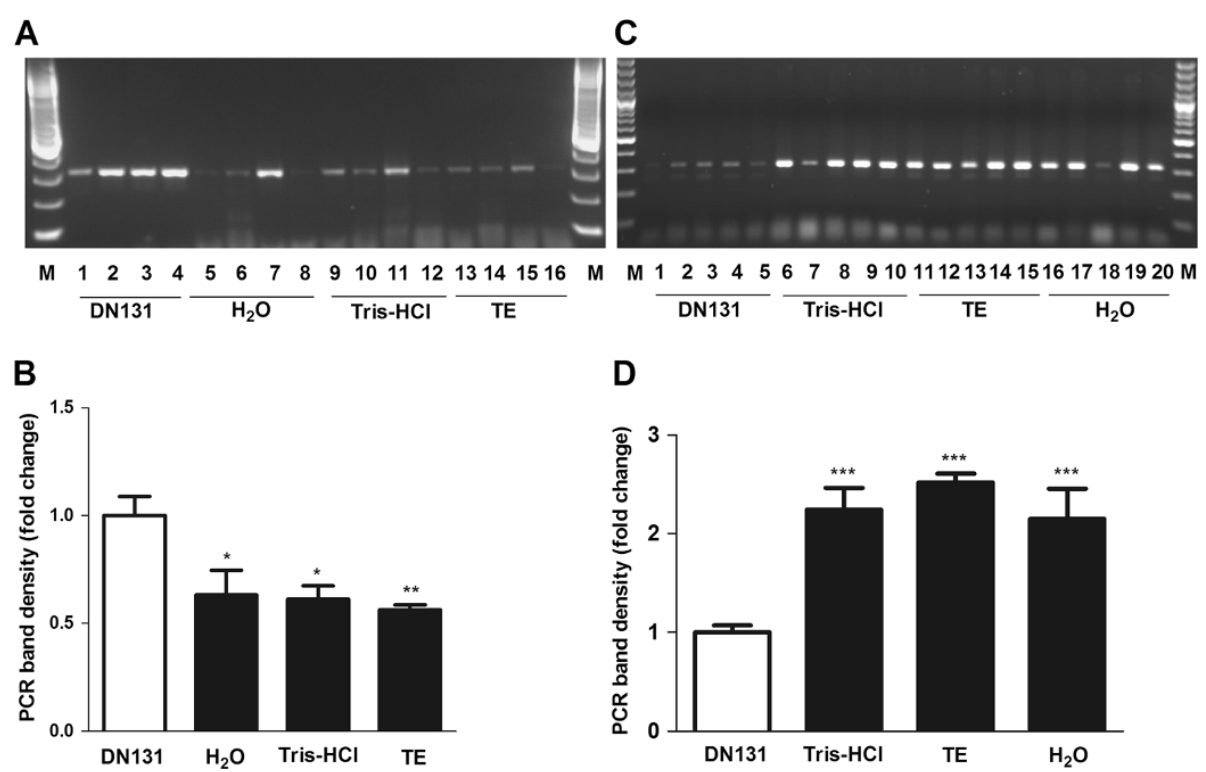

D

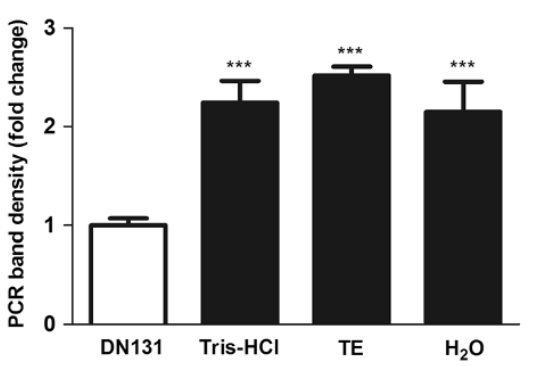

Figure 3 PCR amplification of a DNA fragment of caspase-12 gene covering C125T SNP (rs497116) using 105 DNA samples isolated by different reagents (DN131, Tris- $\mathrm{HCl}, \mathrm{TE}$ and water) with two different PCR amplification systems. A. A representative image of PCR amplified bands separated by a $2 \%$ agarose gel electrophoresis for system 1, which was detailed in Materials and methods. PCR bands were visualized under UV light after ethidium bromide staining; B. PCR band density quantification by Image J for Figure $3 A$. ${ }^{*}, p<0.05 ;{ }^{* *}, p<0.01$, compared to DN131; C. A representative image of PCR amplified bands separated by a $2 \%$ agarose gel electrophoresis for system 2 , which was detailed in Materials and methods; D. PCR band density quantification by Image J for Figure 3C. ***, $p<0.001$, compared to DN131. 
Table 3 Success rates of amplifying caspase-12 C125T SNP (rs497116) by PCR and a Taqman genotyping assay using four different reagents

\begin{tabular}{lccc}
\hline Method & $\begin{array}{c}\text { PCR successful rate } \\
\text { (system 1) } \\
\text { (success\#/total) (\%) }\end{array}$ & $\begin{array}{c}\text { PCR successful rate } \\
\text { (system 2) } \\
\text { (success\#/total) (\%) }\end{array}$ & $\begin{array}{c}\text { Taqman genotyping } \\
\text { successful rate }\end{array}$ \\
\hline $\mathrm{DN131}$ & $(92 / 105)(87.6)$ & $(75 / 105)(71.4)$ & $(74 / 105)(70.5)$ \\
Tris- $\mathrm{HCl}$ & $(94 / 105)(89.5)$ & $(99 / 105)(96.1)$ & $(86 / 105)(81.9)$ \\
$\mathrm{TE}$ & $(77 / 105)(73.3)$ & $(92 / 105)(88.5)$ & $(74 / 105)(70.5)$ \\
$\mathrm{H}_{2} \mathrm{O}$ & $(76 / 105)(72.4)$ & $(82 / 105)(78.1)$ & $(79 / 105)(79.1)$ \\
\hline
\end{tabular}

System 1 and system 2 are two different PCR amplification systems we used and described in Materials and methods.

solutions (water, TE buffer, and Tris- $\mathrm{HCl}$ ) to isolate DNA from old human blood paper cards. The quality and quantity of DNA samples isolated by the three common laboratory solutions are significantly higher than using DN131. The crude DNA isolation procedure minimizes both cost and preparation time, and can be completed in a single microcentrifuge tube in less than 10 min for a single blood card paper. Considering the downstream PCR amplification success rates, the crude DNA extraction using Tris- $\mathrm{HCl}$ without subsequent purification, was comparably successful to a commonly used, commercially available DNA isolation reagent, DN131. The PCR-amplified caspase-12 C125T SNP region can be further used for genotyping via DNA sequencing, restriction fragment length polymorphism and other approaches. Furthermore, the crude DNA isolated using Tris- $\mathrm{HCl}$ can be used for large-scale genotyping by Taqman genotyping system because Taqman genotyping success rates using Tris- $\mathrm{HCl}$ isolated DNA were higher than using DNA isolated by DN131, TE or water. Previously we also showed that Tris $-\mathrm{HCl}$ is a reliable and cost-effective DNA-isolation solution for a mouse genotyping using tails (Sysol et al. 2013).

DNA quality is generally evaluated by the A260/A280 ratio. A ratio of approximately 1.8 is commonly accepted as pure DNA (Wilfinger et al. 1997). If the ratio is lower than 1.8 , it may indicate the presence of protein, phenol or other contaminants which absorb highly at or near $280 \mathrm{~nm}$. In addition, $\mathrm{pH}$ values of DNA solutions will lead to variation of the A260/A280 ratios. In general, acidic solutions will under-represent the 260/280 ratio by $0.2-0.3$, while a basic solution will over-represent the ratio by $0.2-0.3$ (Wilfinger et al. 1997). In this study, DN131 is an alkaline solution (pH11.0) containing polyethylene glycol and other additives, and $\mathrm{pH}$ of the TE solution used is 7.6. This may explain why A260/A280 ratios are relatively higher in DN131 and TE groups than in Tris- $\mathrm{HCl}$ (pH7.4) and water groups. Why does the biggest standard error of A260/A280 ratios occur in DN131 group $(2.07 \pm 0.6)$ with the biggest difference between the minimum and maximum values $(-6.64,52.18$,
Table 2)? It may be attributed to its higher $\mathrm{pH}$ values and the existence of polyethylene glycol and other additives, which may more efficiently extract degraded RNA than other reagents. In general, degraded RNA has higher absorbance at $260 \mathrm{~nm}$ due to its higher ratio of Uracil compared to that of Thymine (Leninger 1975). In addition, DNA quality was also assessed by the A260/ A230 ratio. The A260/A230 ratios for DNA are generally in the range of 2.0-2.2 and higher than the respective A260/A280 ratios (Wilfinger et al. 1997). If the ratio is lower than expected, it may suggest the presence of contaminants. DNA isolated by DN131 has lowest A260/ A230 ratios, which indicate that more contaminants such as carbohydrates, polyethylene glycol and other additives in DN131 reagent which may have high absorbance near $230 \mathrm{~nm}$. To accurately measure quality and quantity of isolated DNA, fluorescence-based DNA measurement is warranted in our future studies.

There are some limitations of this study. First, we used scissors and forceps for blood card cut, which is tedious and not suitable for large-scale studies. A paper puncher can be used to punch out the same size of blood card pieces which is suitable for large-scale studies. Punchers or other tools have to be well cleaned between samples to avoid any sample contaminations. Second, the other commercially available reagents and automatic DNA isolation system were not tested or compared. For example, Soetens et al. (2008) reported automatic easyMAG method which requires a NucliSens easyMAG automated extraction platform (BioMerieux, Boxtel, the Netherlands). This automatic DNA isolation system is faster and better controlled than the manual methods, and thus suitable for large-scale studies. The manual method we used is suitable for small number of blood card samples. Third, we only tested amplification of caspase-12 C125T SNP region, and did not try other genomic regions or blood pathogens. Therefore, in future studies, test of different genomic DNA regions and some blood pathogens by PCR or other methods is warranted.

In summary, this study demonstrates the efficacy of using a crude DNA isolation method from old human 
blood cards. Considering high success rates of PCR amplification and Taqman genotyping, and also availability in a common research laboratory, Tris- $\mathrm{HCl}$ is an alternative and reliable choice for DNA isolation from old blood paper cards. To our knowledge, this is the first systematic study to compare the reliability of this method compared to that of a commercially available reagent.

\section{Competing interest}

The authors declare that they have no competing interest.

\section{Authors' contribution}

Conceived and designed the experiments: JC. Performed the experiments: JC, AF, SS, YG, YW. Analyzed the data: JC, SY. Contributed reagents/materials/ analysis tools: CF, RFM, RGW. Wrote the paper: JC YS, AF, SS. All the authors read and approved the final manuscript.

\section{Acknowledgements}

We thank William W. Wilfinger (Molecular Research Center, Inc) for his technical support. The authors acknowledge the Research Open Access Publishing (ROAAP) Fund of the University of Illinois at Chicago for financial support towards the open access publishing fee for this article.

\begin{abstract}
Author details
'Institute for Genome Sciences, University of Maryland School of Medicine, Baltimore, MD 21201, USA. ${ }^{2}$ Section of Pulmonary, Critical Care, Sleep and Allergy, Department of Medicine, University of Illinois at Chicago, Chicago, IL 60612, USA. ${ }^{3}$ Department of Internal Medicine, Faculty of Health Sciences, University of the Witwatersrand, Johannesburg, South Africa. ${ }^{4}$ Department of Medicine, Northwestern University, Chicago, IL 60611, USA.
\end{abstract}

Received: 5 August 2013 Accepted: 7 November 2013

Published: 19 November 2013

\section{References}

Ataei S, Nateghpour M, Hajjaran H, Edrissian GH, Foroushani AR (2011) High specificity of semi-nested multiplex PCR using dried blood spots on DNA Banking Card in comparison with frozen liquid blood for detection of Plasmodium falciparum and Plasmodium vivax. J Clin Lab Anal 25(3):185-190

Barbaro A, Cormaci P, Barbaro A, Louahlia S (2004) DNA analysis in a case of serial murderers. Int Congr Ser 1261:465-467

Chomczynski P, Mackey K, Drews R, Wilfinger W (1997) DNAzol: a reagent for the rapid isolation of genomic DNA. Biotechniques 22(3):550-553

Chomczynski P, Wilfinger W, Mackey K (1998) Isolation of genomic DNA from human, animal, and plant samples with DNAzol reagents. Mol Biotechnol $9(1): 1-5$

Dobbs L, Madigan MN, Carter AB, Earls L (2002) Use of FTA gene guard filter paper for the storage and transportation of tumor cells for molecular testing. Arch Pathol Lab Med 126(1):56-63

Haak PT, Busik JV, Kort EJ, Tikhonenko M, Paneth N, Resau JH (2009) Archived unfrozen neonatal blood spots are amenable to quantitative gene expression analysis. Neonatology 95(3):210-216

Hardin J, Finnell RH, Wong D, Hogan ME, Horovitz J, Shu J, Shaw GM (2009) Whole genome microarray analysis, from neonatal blood paper cards. BMC Genet 10:38

Klassen TL, von Rüden EL, Drabek J, Noebels JL, Goldman AM (2012) Comparative analytical utility of DNA derived from alternative human specimens for molecular autopsy and diagnostics. J Mol Diagn 14(5):451-457

Klassen TL, Drabek J, Tomson T, Sveinsson O, von Döbeln U, Noebels JL, Goldman AM (2013) Visual automated fluorescence electrophoresis provides simultaneous quality, quantity, and molecular weight spectra for genomic DNA from archived neonatal blood spots. J Mol Diagn 15(3):283-290

Knowles SC, Fenton A, Pedersen AB (2012) Epidemiology and fitness effects of wood mouse herpesvirus in a natural host population. J Gen Virol 93(Pt 11):2447-2456

Leninger AL (1975) Biochemistry, 2nd edn. Worth Publishers, New York
Mackey K, Steinkamp A, Chomczynski P (1998) DNA extraction from small blood volumes and single-tube DNA extraction and amplification using blood filter cards. Mol Biotechnol 9:1-5

Mas S, Crescenti A, Gassó P, Vidal-Taboada JM, Lafuente A (2007) DNA cards: determinants of DNA yield and quality in collecting genetic samples for pharmacogenetic studies. Basic Clin Pharmacol Toxicol 101(2):132-137

Moss D, Harbison S-A, Saul DJ (2003) An easily automated, closed tube forensic DNA extraction procedure using a thermostable proteinase. Int I Legal Med 117:340-349

Myles P, Cui I (2007) Using the Bland-Altman method to measure agreement with repeated measures. Br J Anaesth 99(3):309-311

Phyo AP, Nkhoma S, Stepniewska K, Ashley EA, Nair S, McGready R, ler Moo C, Al-Saai S, Dondorp AM, Lwin KM, Singhasivanon P, Day NP, White NJ, Anderson TJ, Nosten F (2012) Emergence of artemisinin-resistant malaria on the western border of Thailand: a longitudinal study. Lancet 379(9830):1960-1966

Richard I, Somiari E, Adebiyi L, Ukachukwu I, Mba FA, Anthony Al, Brainard OM, Lubert S, Larson C, Russell S, Bharathan N, Somiari SB (2011) STR analysis of human DNA samples after dry-state ambient temperature storage in geneplates. Open Forensic Sci J 4:30-35

Rohland N, Hofreiter M (2007) Comparison and optimization of ancient DNA extraction. Biotechniques 42(3):343-352

Soetens O, Vauloup-Fellous C, Foulon I, Dubreuil P, De Saeger B, Grangeot-Keros L, Naessens A (2008) Evaluation of different cytomegalovirus (CMV) DNA PCR protocols for analysis of dried blood spots from consecutive cases of neonates with congenital CMV infections. J Clin Microbiol 46(3):943-946

Sysol JR, Kempf C, Helton MN, Dong Y, Zhu D, Sun H, Garcia JG, Machado RF, Chen J (2013) Evaluation of a reliable and cost-effective method of DNA isolation for mouse genotyping. Biotechnol Lett 35(4):509-514

Turner AK, Begon M, Jackson JA, Bradley JE, Paterson S (2011) Genetic diversity in cytokines associated with immune variation and resistance to multiple pathogens in a natural rodent population. PLoS Genet 7(10):e1002343

Wilfinger WW, Mackey K, Chomczynski P (1997) Effect of pH and ionic strength on the spectrophotometric assessment of nucleic acid purity. Biotechniques 22:474-481

doi:10.1186/2193-1801-2-616

Cite this article as: Song et al:: A reliable and effective method of DNA isolation from old human blood paper cards. SpringerPlus 2013 2:616.

\section{Submit your manuscript to a SpringerOpen ${ }^{\odot}$ journal and benefit from:}

- Convenient online submission

Rigorous peer review

- Immediate publication on acceptance

- Open access: articles freely available online

- High visibility within the field

- Retaining the copyright to your article

Submit your next manuscript at $>$ springeropen.com 